\title{
Ozarkodina remscheidensis plexus conodonts from the upper Ludlow (Silurian) of the Welsh Borderland and Wales
}

\author{
C. GILES MILLER* \& RICHARI J. ALDRIDGE \\ Department of Geology, University of Leicester, Leicester LE1 7RH, UK. \\ *Present address: Department of Palaeontology, Natural History Museum, Cromwell Road, London SW7 5BD, UK.
}

\begin{abstract}
Three subspecies of the conodont Ozarkodina remscheidensis Ziegler, 1960, are described from the late Ludlow (Silurian) of the Welsh Borderland and Wales, including a new subspecies $O$. $r$. baccata. Four discrete element types which occur in association are also described and interpreted as possible members of the Ozarkodina remscheidensis apparatus. J. Micropalaeontol. 16(1): 41-49, May 1997.
\end{abstract}

\section{INTRODUCTION}

Walliser $(1962,1964)$ proposed the first Silurian conodont biozonation, based on the Cellon section in the Carnic Alps. This scheme included a late Silurian eosteinhornensis Biozone characterized by Ozarkodina remscheidensis eosteinhornensis (Walliser). Since then, $O$. remscheidensis plexus conodonts have been recognized in late Silurian and early Devonian sections worldwide (Fig. 1) and a number of authors have suggested revisions to Walliser's original biozonal scheme. A review of early modifications has been given by Cooper (1980). More recent biozonal revisions have included that of Aldridge \& Schönlaub (1989, fig. 173), who showed the eosteinhornensis Biozone spanning much of the Prídolí, with its base above the last occurrence of Ozarkodina crispa (Walliser) and its upper limit at the first occurrence of Icriodus woschmidti woschmidti (Ziegler). Kleffner (1989) used graphical correlation on data from 30 sections in America and Europe to establish a composite biozonal scheme including a late Ludlow to late Prídolí remscheidensis Biozone.

We have made detailed conodont collections around the Ludlow-Pridoli boundary in the Welsh Borderland and Wales, and these have provided new data on the distribution of conodonts of the remscheidensis plexus at this critical level. The majority of the specimens were extracted from limestones or slightly calcareous rocks using $10 \%$ acetic acid. Residues were dried and sieved to $75 \mathrm{~mm}$ and the heavy fraction (including conodonts) separated out using an aqueous solution of the inert heavy liquid sodium polytungstate (manufactured by Sometu, Berlin) at a specific gravity of 2.80 . Locality and sample numbers are those used by Miller \& Aldridge (1993, p. 244). All figured specimens are deposited at the Natural History Museum, London.

Previously, Walliser (1966), Collinson \& Druce (1966), Aldridge (1975, 1985) and Aldridge \& Schönlaub (1989) have reported $O$. remscheidensis eosteinhornensis from the Welsh Borderland. In this contribution we provide the first description of associated members of the remscheidensis plexus that occur with $O, r$. eosteinhornensis, including a new subspecies $O . r$. baccata. The use of subspecies in conodont taxonomy has a somewhat chequered history. They have been used to differentiate populations of species that are clearly chronologically (e.g. Walliser (1964) for Ozarkodina sagitta rehana and $O$. $s$. sagitta, now considered index fossils for sucessive zones

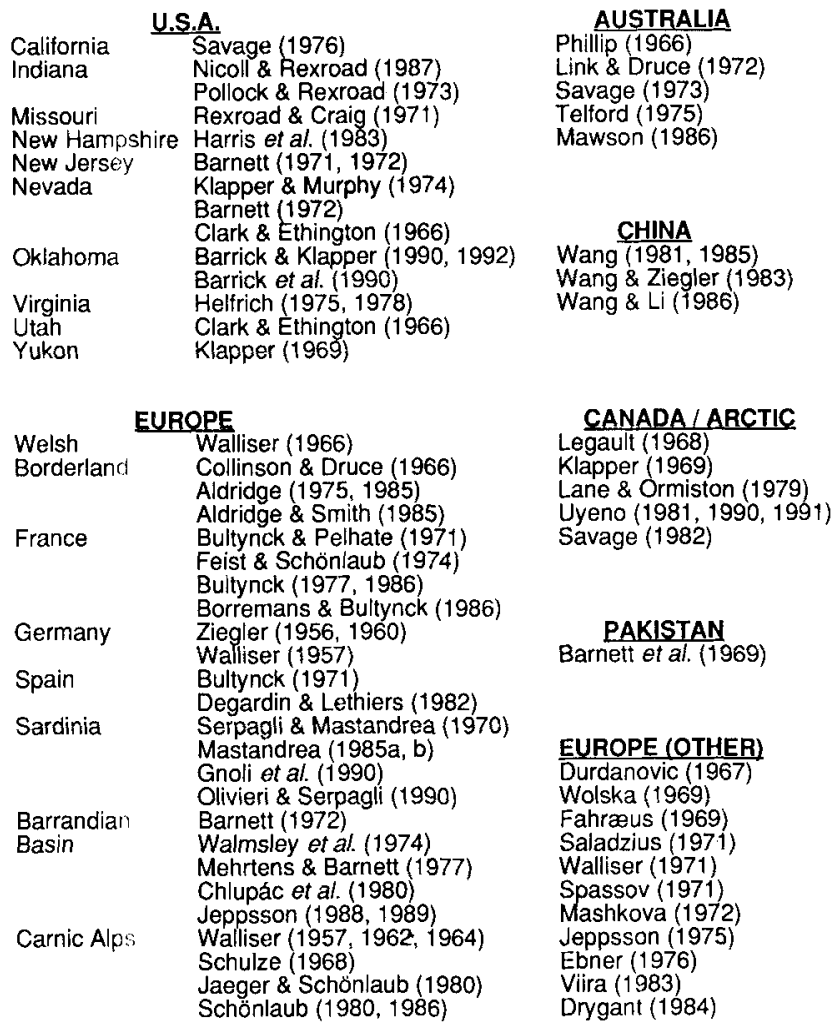

Fig. 1. Publications that figure or document Ozarkodina remscheidensis plexus conodonts, arranged geographically.

(Aldridge \& Schönlaub, 1989)) or geographically separated (e.g. Apsidognathus tuberculatus tuberculatus Walliser, 1964 and A. $t$. arcticus Armstrong, 1990). Subspecies have also been applied to morphological variants that overlap in space and time (e.g. Higgins (1975) for the Carboniferous species Gnathodus girtyi). Some authors have preferred to designate morphotypes for the latter situation (e.g. Klapper \& Murphy (1974) for Ozarkodina confluens), giving each morphotype a different Greek letter. The subspecies designated here, $O . r$. baccata, forms a distinct and potentially biostratigraphically useful population in late Ludlow samples from the Welsh Borderland, 
although specimens of the other two subspecies do occur in association. As subspecific categories already exist for $O$. remscheidensis, it is preferential to differentiate this population as a third subspecies, rather than add morphotype letters to one of the existing subspecies.

\author{
SYSTEMATIC PALAEONTOLOGY \\ Phylum Chordata Bateson, 1886 \\ Class Conodonta Pander, 1856 \\ Order Ozarkodinida Dzik, 1976 \\ Family Spathognathodontidae Hass, 1959 \\ Genus Ozarkodina Branson \& Mehl, 1933 \\ Ozarkodina remscheidensis baccata ssp. nov.
}

(Pl. 1, figs 1-18; Fig. 2)

1985 Ozarkodina remscheidensis subsp. nov. Aldridge: 90, pl. 3.4, fig. $17(\mathrm{~Pa})$.

Derivation of name. Subspecies named baccata (Latin $=$ yew tree) as first specimens were collected from an exposure in the car park opposite the Yew Tree Inn at Prior's Frome near Hereford (loc. 24).

Diagnosis. $\mathrm{Pa}$ element with straight blade bearing irregular mostly broad denticles, crowded near to inconspicuous cusp which is central or very slightly to posterior of midlength. Posterior process and denticles decrease in height distally; basal margin weakly concave. Asymmetrically flared cavity with one side more flared and more pinched.

Holotype. Natural History Museum, London, UK, No. PM X $1156(\mathrm{~Pa})$. Holotype figured in Pl. 1, figs 9, 12.

Material. $20 \mathrm{~Pa}$ elements.

Localities and horizons. (Figs 3,4) Holotype $2 \mathrm{~m}$ below top of Whitcliffe Formation: sample 39/1, Aston Munslow, Corve Dale, Shropshire, GR SO 51248658 (loc. 7a). Upper Whitcliffe Formation: sample 15c/2, Whitcliffe Quarry, Ludlow, Shropshire (loc. 15c); samples $77 / 2$ and 18/1, Ludford Corner, Ludlow, Shropshire (loc. 18). Upper Perton Beds: samples 162/2 and 24a/2a, Prior's Frome, Hereford and Worcester (loc. 24a). Upper Llangibby Beds: sample 33/3, Brook House, Usk, Gwent (loc. 33).

Description. Pa element (Pl. 1, figs 1-18; Fig. 2) carminate with inconspicuous cusp, central or just posterior of cavity. Posterior process with four to six denticles; two proximal denticles of similar shape and size to cusp; one specimen with tiny accessory denticle fused to proximal denticle. Remaining denticles increasingly smaller distally as process diminishes posteriorly
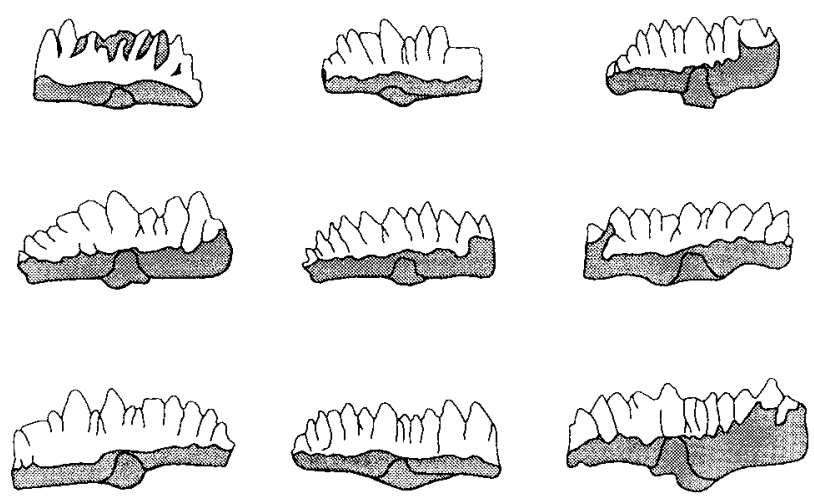

Ozarkodina remscheidensis baccata ssp. nov. Pa element
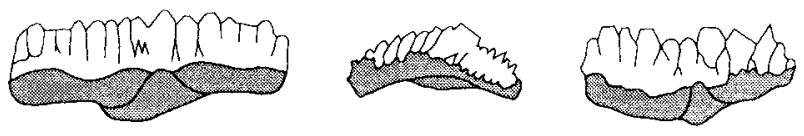

\section{o. remscheidensis \\ eosteinhornensis}

Pa element

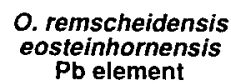

O. remscheidensis remscheidensis Pa element
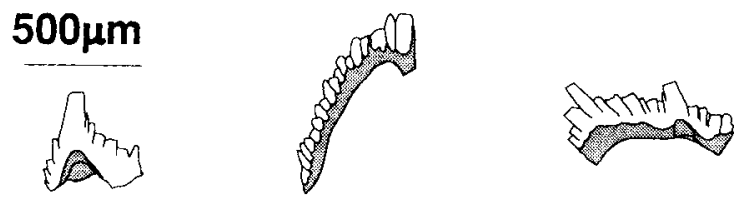

\section{O. remscheidensis$$
\text { ssp. }
$$

M morph A
o. remscheidensis
ssp.
$M$ morph B
O. remscheidensis ssp.
Sb element

Fig. 2. Camera lucida drawings in lateral view showing white matter distribution in elements of $O . r$. baccata, O.r. eosteinhornensis, $O . r$. remscheidensis and $O, r$. ssp. Specimen numbers from top left: $\mathrm{PM} \mathrm{X}$ 1292, PM X 1293, PM X 1294, PM X 1296, PM X 1295, PM X 1156, PM X 1298, PM X 1297, PM X 1157, PM X 1164, PM X 1259, PM X 1277 , PM X 1169, PM X 1180, PM X 1168.

to three quarters medial height; process terminates with small step-like extension beyond last denticle. Posterior aboral surface slightly concave. Anterior process same length as posterior; denticles number four in juvenile specimens and up to six in

\section{Explanation of Plate 1}

Figs 1-18. Ozarkodina remscheidensis baccata ssp. nov., Pa elements. Figs 1, 4. PM X 1292, sample 162/2, Upper Perton Beds, Prior's Frome, Hereford \& Worcester (loc. 24a), ×55: Fig. 1. Lateral; Fig. 4. Oral. Figs 2, 5. PM X 1293, sample and locality as for Fig. 1, $\times 45:$ Fig. 2. Lateral; Fig. 5. Oral. Figs 3, 6. PM X 1294, sample and locality as for Fig. 1, ×50. Fig. 3. Lateral; Fig. 6. Oral. Figs 7, 10. PM X 1296, sample 161/1, Upper Perton Beds, Perton, Hereford \& Worcester (loc. 23b), ×45: Fig. 7. Lateral; Fig. 10. Oral. Figs 8, 11. PM X 1295, sample and locality as for Fig. 1, $\times 50:$ Fig. 8. Lateral; Fig. 11. Oral. Figs 9, 12. PM X 1156, holotype, sample 39/1, Whitcliffe Formation, opposite the Swan Inn, Aston Munslow, Corve Dale, Shropshire (loc. 7a), ×45; Fig. 9. Lateral; Fig. 11. Oral. Figs 13, 16. PM X 1298, sample and locality as for Fig. 1, ×45: Fig. 13. Lateral; Fig. 16. Oral. Figs 14, 17. PM X 1297, sample and locality as for fig. 1, $\times 45$. Fig. 14. Lateral; Fig. 17, Oral. Figs 15, 18. PM X 1157, sample and locality as for Fig. 8 , $\times$ 40. Fig. 15. Lateral; Fig. 18, Oral. Figs 15, 18. PM X 1157, sample and locality as for Fig. 1, ×40. Fig. 15. Lateral; Fig. 18, Oral. Figs 19, 20, 22, 23. Ozarkodina remscheidensis eosteinhornensis (Walliser, 1964). Figs 19, 22. Pa element, PM X 1164, sample 8/1, Whitcliffe Formation, Diddlebury, Corve Dale, Shropshire (loc. 8), $\times$ 30: Fig. 19. Lateral; Fig. 22. Oral. Figs 20, 23. Fragment showing cavity and posterior process of Pa element, PM X 1190, sample 18/1, Upper Whitcliffe Formation, Ludford Corner, Ludlow, Shropshire (loc. 18), $\times 50$ : Fig. 20. Lateral; Fig. 23. Oral. Figs 21, 24. Ozarkodina remscheidensis remscheidensis (Ziegler, 1960). Pa element, PM X 1277, sample 31b/3, Whitcliffe Formation, foreshore of Severn Estuary, Tite's Point, Gloucestershire (loc. 31b), ×45: Fig. 21. Lateral; Fig. 24. Oral. 

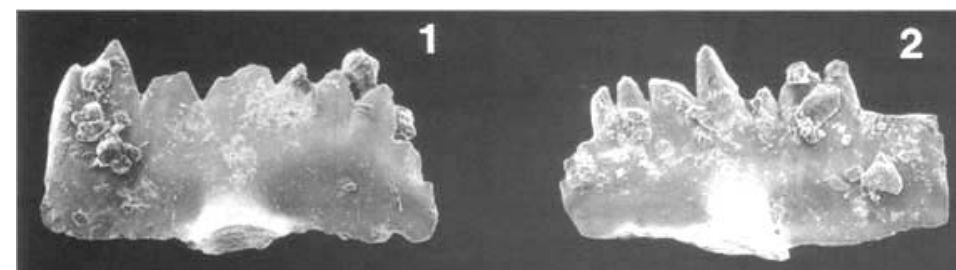

4

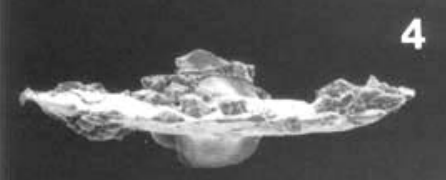

7

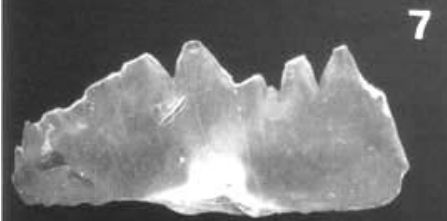

10
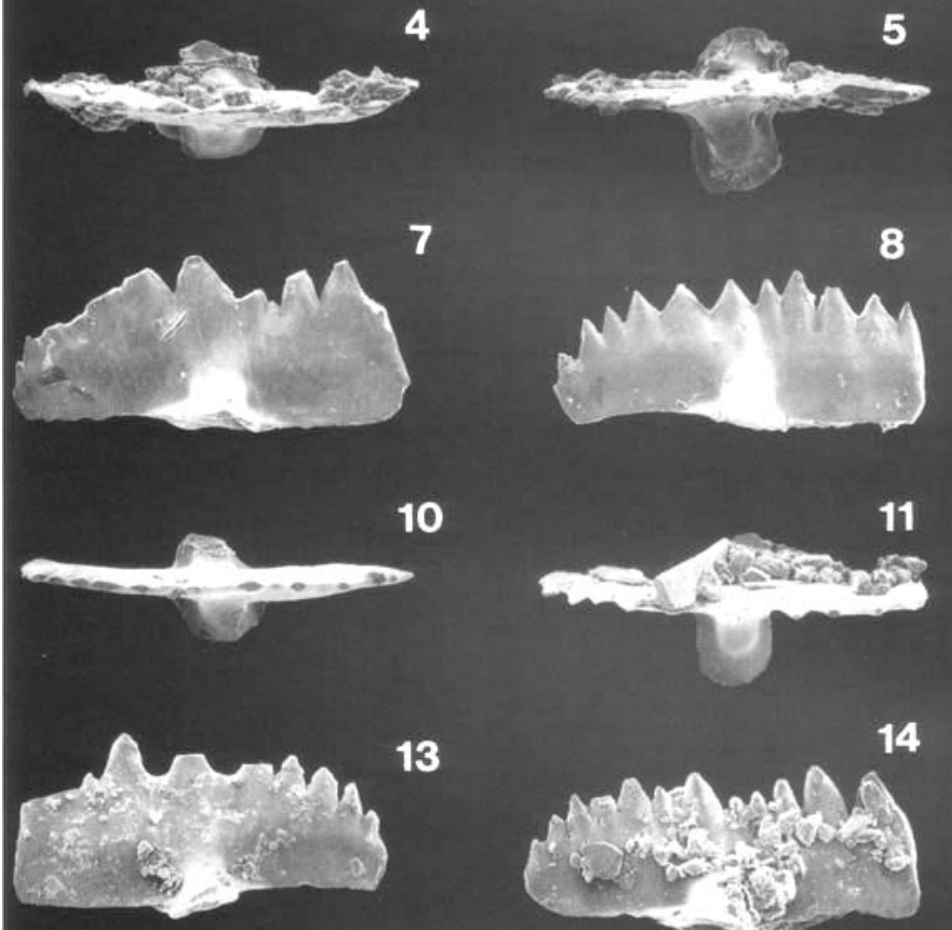

8

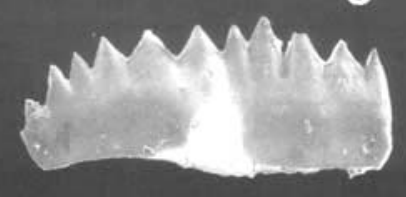

11

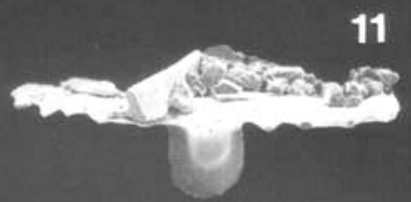

14

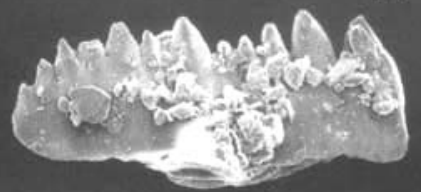

17

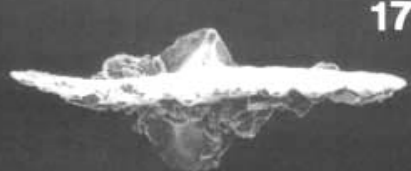

20

19

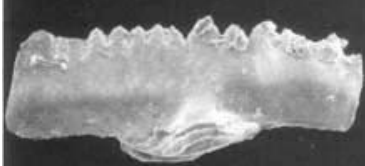

16
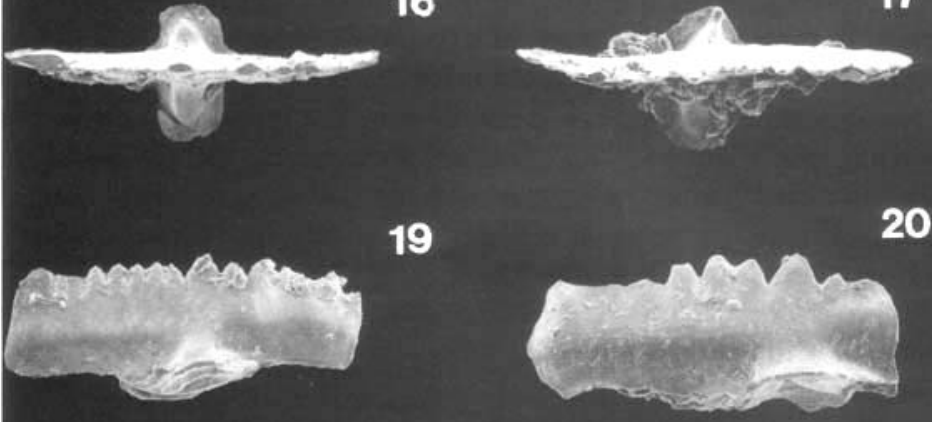

23
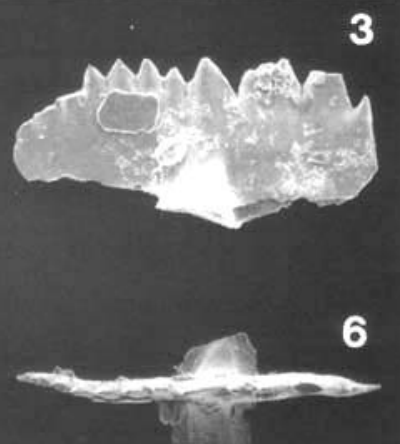

9
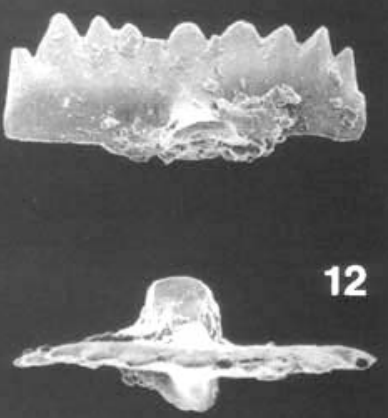

15

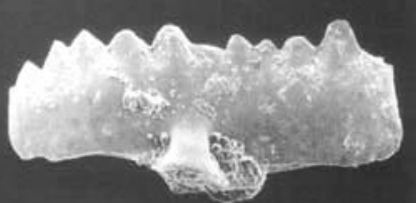

18

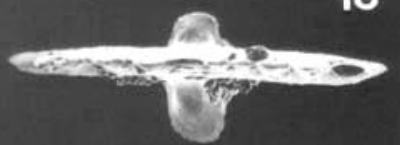

21

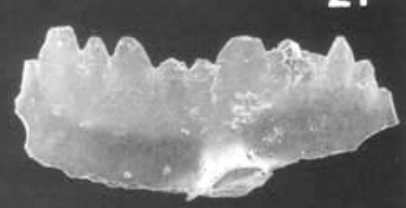

24
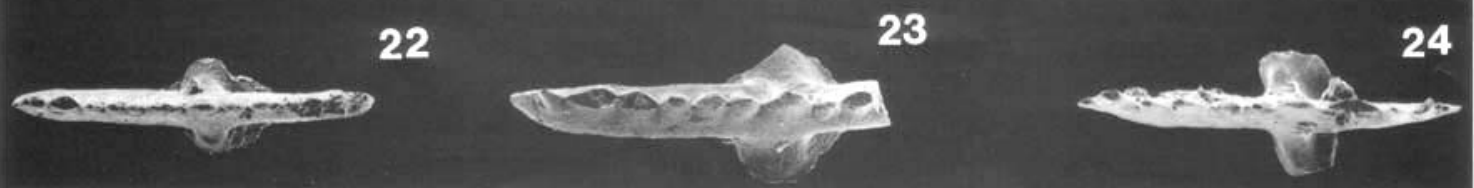


\begin{tabular}{|c|c|c|c|c|c|c|c|c|c|c|c|c|c|c|c|c|c|c|c|}
\hline Sample & $\begin{array}{c}5 c \\
1\end{array}$ & $\begin{array}{c}39 \\
1\end{array}$ & $\begin{array}{l}8 \\
1\end{array}$ & $14 c$ & $\begin{array}{c}74 \\
1\end{array}$ & $\begin{array}{c}15 \mathrm{c} \\
2\end{array}$ & $\begin{array}{c}77 \\
2\end{array}$ & $\begin{array}{c}18 \\
1\end{array}$ & $\begin{array}{l}20 \\
1 \mathrm{~b}\end{array}$ & $\begin{array}{c}160 \\
1\end{array}$ & $\begin{array}{c}161 \\
1\end{array}$ & $\begin{array}{c}24 a \\
2 a\end{array}$ & $\begin{array}{c}162 \\
2\end{array}$ & $\begin{array}{c}31 b \\
1\end{array}$ & $\begin{array}{c}31 \mathrm{~b} \\
3\end{array}$ & $\begin{array}{c}31 b \\
4\end{array}$ & $\begin{array}{c}33 \\
2\end{array}$ & $\begin{array}{c}33 \\
3\end{array}$ & $\begin{array}{c}33 \\
4\end{array}$ \\
\hline Total no. conodont elements & 1260 & 238 & 57 & 194 & 524 & 261 & 67 & 195 & 551 & 1320 & 1627 & 1010 & 1744 & 343 & 435 & 486 & 123 & 176 & 45 \\
\hline $\begin{array}{ll}\text { O. remscheidensis baccata } & \mathrm{Pa} \\
\text { O.r.cf. baccata } & \mathrm{Pa} \\
\end{array}$ & $\begin{array}{l}2 \\
3 \\
\end{array}$ & $\begin{array}{l}3 \\
2 \\
\end{array}$ & & & & $\begin{array}{l}1 \\
1\end{array}$ & $\overline{1}$ & $\begin{array}{l}3 \\
1\end{array}$ & & & & $\begin{array}{l}3 \\
2\end{array}$ & $\begin{array}{l}1 \\
1\end{array}$ & & & 1 & 1 & $\overline{1}$ & \\
\hline \begin{tabular}{ll|} 
O.r. eosteinhornensis & $\mathrm{Pa}$ \\
O.r. cf. eost. & $\mathrm{Pb}$ \\
& $\mathrm{Pa}$
\end{tabular} & 2 & 2 & $\begin{array}{l}1 \\
1\end{array}$ & 1 & 6 & 1 & 5 & $\begin{array}{l}1 \\
2 \\
3\end{array}$ & 1 & 1 & 1 & 1 & & $\begin{array}{l}1 \\
1\end{array}$ & 1 & 2 & & & \\
\hline O.r. remscheidensis & & & & & & & & & & & 1 & & & & 1 & & & & \\
\hline
\end{tabular}

Fig. 3. Frequencies of $O$. remscheidensis elements in samples from the Welsh Borderland and Wales. Samples and localities as listed by Miller \& Aldridge (1993).

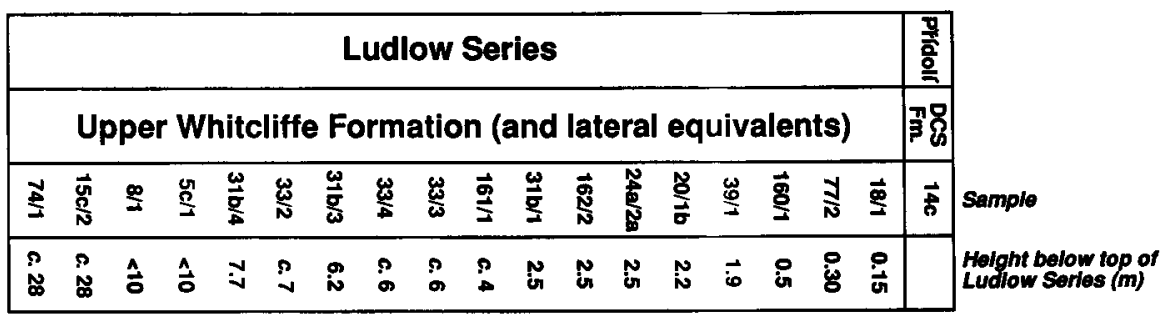

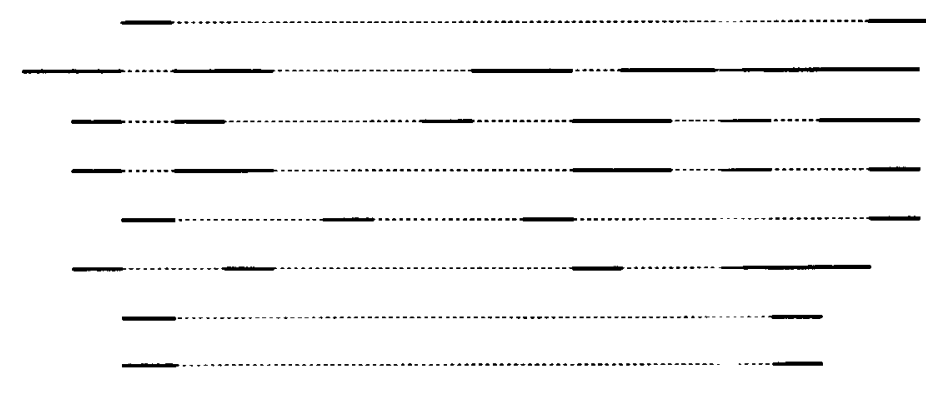

\section{O. r. eosteinhornensis $\mathrm{Pa}$ \\ O. r. eosteinhormensis $\mathrm{Pb}$ \\ O. r. baccata $\mathrm{Pa}$ \\ O. r. cf. baccata $\mathrm{Pa}$ \\ O. r. cf. eosteinhornensis $\mathrm{Pa}$ \\ o. r. ssp. M morph B \\ O. r. ssp. M morph A \\ o. r. ssp. Sb \\ O. r. remscheidensis $\mathrm{Pa}$}

Fig. 4. Stratigraphic distribution of $O$. remscheidensis plexus conodonts from Wales and the Welsh Borderland. Samples are arranged in approximate stratigraphical order with height below the top of the Ludlow Series given when possible. DCS = Downton Castle Sandstone. Lateral equivalents for the Upper Whitcliffe Formation are given by Miller \& Aldridge (1993).

more mature specimens, of uneven size, crowded close to cusp, becoming slightly more isolated distally. Terminal denticle slightly lower than adjacent denticle, with anterior margin sloping very slightly to anterior and rounded antero-aborally. Anterior process with straight aboral margin, decreasing much more gradually in height than posterior process. Shallow cavity extends entire length of element, flared at mid-length with rounded lips; flaring asymmetrical, much stronger on one side of element. Oral surface of flare pinched. White matter present in cusp and all denticles, mostly as single solid block; base of white matter parallel to aboral margin of element or rising anteriorly from beneath cusp (Fig. 2).

Dimensions. Length and maximum height $(\mu \mathrm{m})$ are given for each specimen: PM X 1156 (holotype); 812, 334. PM X 1157; 980, 406. PM X 1292; 720, 380. PM X 1293; 670, 456. PM X 1294; 760, 342. PM X 1295; 811, 342. PM X 1296; 900, 394. PM X 1297; 887, 367. PM X 1298; 932, 444.

Remarks. Before 1974, subspecies of $O$. remscheidensis were treated by various authors as subspecies of Ozarkodina steinhornensis (Ziegler, 1956). Mashkova (1972), however, used a bedding plane assemblage to reconstruct the apparatus of $O$. steinhornensis and showed that it possessed an Sa element with a denticulate posterior process. On Sa elements of the reconstructed apparatuses of the taxa discussed here a posterior process is not developed (see Mashkova (1972), pl. 2), and Klapper \& Murphy (1974, pp. 39, 40) argued that the appropriate species name should be remscheidensis rather than steinhornensis.

$O$. r. baccata is distinct from other late Silurian subspecies, but is closer to $O$. r. eosteinhornensis than to $O$.r. remscheidensis. There is a clear angle between the basal margins of the anterior and posterior process of the $\mathrm{Pa}$ element of $O$.r. remscheidensis, which also displays well developed denticles towards the anterior. The Pa element of $O$. r. baccata is distinct from that of $O$. r. eosteinhornensis as it has a central, asymmetrically flared cavity pinched on one side and broader denticles which are not 


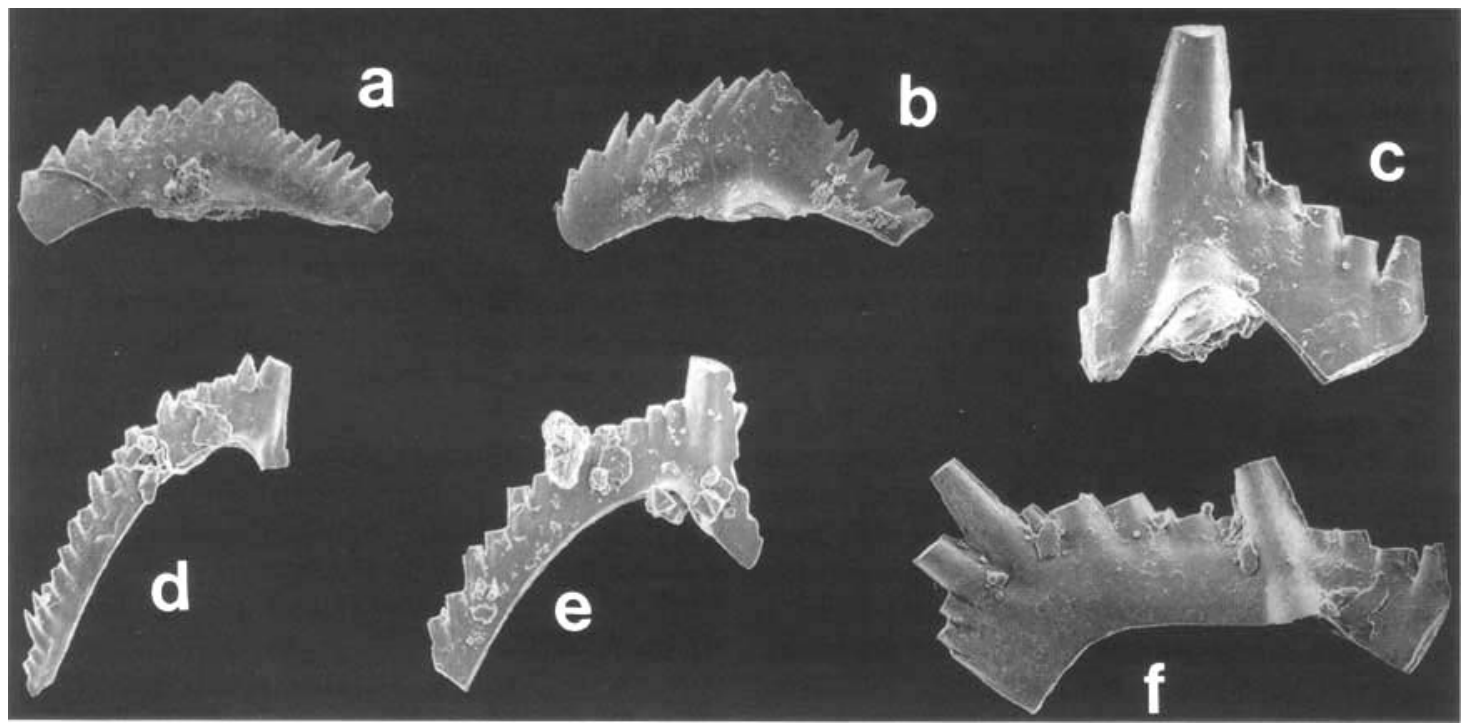

Fig. 5. a, b. Ozarkodina remscheidensis eosteinhornensis (Walliser, 1964). a. Pb element, lateral view, PM X 1259, sample 39/1, Whitcliffe Formation, opposite the Swan Inn, Aston Munslow, Corve Dale, Shropshire (loc. 7a), $\times 50$. b. Pb clement, lateral view, specimen now lost, sample 24a/2a, Upper Perton Beds, Prior's Frome, Hereford \& Worcester (loc. 24a), ×45. c-f. Ozarkodina remscheidensis spp. c. M element morphotype A, lateral, PM X 1169, sample 8/1, Whitcliffe Formation, Diddlebury, Corve Dale, Shropshire (loc. 8), ×30. d, e. M element morphotype B. d. Lateral, PM X 1180, sample 15c/2, Upper Whitcliffe Formation, Whitcliffe Quarry, Ludlow, Shropshire (loc. 15c), $\times 50$. e. Lateral, PM X 1265, sample 162/2, Upper Perton Beds, locality as for Fig. 5b, $\times 70$. f. Sb element, lateral, PM X 1168, sample and locality as for Fig. 5 c, $\times 70$.

fused above the cavity. Philip (1966, fig. 8A) figured a similar Pa element from the Lower Devonian of Australia as Spathognathodus steinhornensis buchanensis Philip, but the denticles vary from relatively large, crowded and almost discrete to small, crowded and fused. The anteriormost denticles of $S$. $s$. buchanensis are sometimes enlarged (Philip 1966, fig. 8B), whereas the denticles on $O$. r. baccata do not show a marked size increase anteriorly and the anteriormost denticle is always smaller and lower than its neighbour. The majority of $S . S$. buchanensis specimens figured by Philip (1966, pl. 2) are markedly bowed in oral view whereas all the specimens of $O$. $r$. baccata from the Welsh Borderland have straight to very slightly bowed blades (Pl. 1). Schönlaub (1980, pl. 6, fig. 11 as $O$. $r$. remscheidensis) and Drygant (1984, pl. 13, fig. 11 as Spathognathodus eosteinhornensis) also figured specimens with similar dentition to $O$. r. baccata but the nature of the cavity is unclear on both illustrations.

The apparatus of $O$. r. baccata is unknown. It is probable that the $\mathrm{Pb}$ element is indistinguishable from that of $O . r$. eosteinhornensis, which is relatively over-represented in our collections (Fig. 3). Aldridge (1985, p. 90) suggested that the $\mathrm{Pa}$ element is associated with ramiform elements bearing crowded denticles of alternating size'. An Sb element with appropriate morphology (Fig. 5f) occurs in the Whitcliffe Formation and is possibly from the apparatus of $O$. r. baccata, although it has not yet been found in association with the $\mathrm{Pa}$ element. No other unassigned elements with alternating denticulation have been recovered from the late Silurian of the Welsh Borderland. Specimens identified (Figs 3, 4) as O. r. cf. baccata or O. r. cf. eosteinhornensis are incomplete or abraded. Many of the faunas have been significantly affected by hydrodynamic sorting and $\mathrm{Pa}$ element over-representation is common in other species from the same samples. This could explain the poor representation of the other elements of the apparatus.

Jeppsson (1975) noted that conodonts of the $O$. steinhornensis (remscheidensis) group tend to form local populations. $O$. $r$. baccata probably represents a localized subspecies of $O$. remscheidensis that may have been confined to the Welsh Borderland in the late Silurian.

\section{Ozarkodina remscheidensis eosteinhornensis (Walliser, 1964)}

(P1. 1, figs 19, 20, 22, 23, Fig. 2, Figs 5a, b)

1964 Spathognathodus steinhornensis eosteinhornensis Walliser: 85-86, 19-25, pl. 9, fig. 15, pl. 20, figs 7, 8, 12-16 (Pa).

1964 Ozarkodina typica denckmanni Ziegler; Walliser: 61, pl. 9, fig. 14; pl. 26, figs 3-11 (Pb). See Walliser (1964, p. 61) for furthur synonymy of $\mathrm{Pb}$ element.

1972 Ozarkodina steinhornensis eosteinhornensis Walliser; Mashkova: 83 , pl. 2, figs 25-30 (whole apparatus).

1973 Ozarkodina remscheidensis eosteinhornensis (Walliser); Klapper: 243-244, pl. 2, fig. 5 (Pa).

For synonymy see Uyeno (1990, pp. 94-95) and add the following:

1976 Ozarkodina typica typica Ziegler; Ebner: 289, pl. 4, fig. 11 $(\mathrm{Pb})$.

1989 Ozarkodina steinhornensis eosteinhornensis Walliser; Jeppsson: 28 , pl. 2, fig. $4(\mathrm{~Pa})$.

1992 Ozarkodina remscheidensis eosteinhornensis (Walliser); Barrick \& Klapper: 48, pl. 6, figs 2-4 (Pa).

Diagnosis. ' $\mathrm{Pa}$ with a long blade of relatively even denticulation, an inconspicuous cusp; cavity slightly posterior of mid-length with widely flaring lips, commonly pinched' (Aldridge, 1985, p. 90).

Holotype. Geologisch-Paläontologische Institut, Phillips Universität, Marburg/Lahn, FRG., No. Wa 540/4 (Pa). Figured by 
Walliser, 1964, pl. 20, fig. 21, from the Cellon section, Carnic Alps.

Material. 28 elements ( $3 \mathrm{~Pa}$ and $25 \mathrm{~Pb}$ elements).

Localities and horizons. (Figs 3, 4) Whitcliffe Formation: sample 8/1, Diddlebury, Corve Dale, Shropshire (loc. 8). Upper Whitcliffe Formation: sample 18/1, Ludford Corner, Ludlow, Shropshire (loc. 18). Ludlow Bone Bed Member, Downton Castle Sandstone Formation: Ludford Corner, Ludlow, Shropshire (Walliser, 1966). Platyschisma Shale Member, Downton Castle Sandstone Formation (Př́idolí): sample 14c, Downton, Shropshire (loc. 14c).

Description. Pa element (P1. 1, figs 19, 20, 22, 23; Fig. 2) carminate, with uneven denticulation; cavity and indistinct cusp situated slightly to posterior of mid-length. Cusp triangular, posterior edge sloping at $60-70^{\circ}$, anterior edge at $45^{\circ}$. Both processes lenticular in section with distinct thickened area extending entire length of element, parallel with oral margin, at a level confluent with the uppermost extension of the cavity. Posterior process with slightly concave oral margin, decreasing slightly in height distally; second or third denticle from cusp dominant, terminal two denticles more isolated than remainder. Anterior process of constant height with straight aboral margin, longer than posterior, with five fused denticles of roughly similar proportion to anterior of cusp; terminal two denticles larger, broader and more isolated. Termination of anterior process inclined slightly to anterior, rounded postero-aborally. Cavity circular under cusp, drawn out under entire length of both processes, lips pinched and inclined slightly to posterior. Basal body present in some specimens, extending slightly beyond and below cavity lips. White matter fills cusp and all denticles, extending to top of thickened area, parallel with oral margin. Two denticles either side of cusp have accessory white matter patches between them (Fig. 2).

$P b$ element (Fig. 2, Figs 5a, b) angulate with cusp strongly inclined to posterior. Angle between aboral margins of processes $150-160^{\circ}$. Anterior process taller than posterior with proximal denticles strongly fused to cusp, denticles becoming more isolated and more erect distally, with finai three denticles rapidly decreasing in size. Posterior process decreasing in height distally, bearing discrete denticles of similar size and posterior inclination. Cavity elongate, narrow, tapering distally, extending entire length of both processes. Posteriorly inclined distinct white matter patches beneath each denticle decreasing in size distally on anterior process, extending almost to the cavity for entire length of posterior process.

Remarks. The diagnosis given by Walliser $(1964$, p. 85$)$ is unclear and there is disagreement regarding the limits of this subspecies. Jeppsson $(1975,1989)$ suggested a restricted definition including only specimens with fused, almost indistinct denticles above the cavity. Barrick \& Klapper (1992) argued for a much broader concept to reflect the original inclusion by Walliser (1964) of specimens with fused denticles above the cavity and specimens with even denticulation. The Welsh Borderland material has fused denticles above the cavity but there is no development of denticulation on the basal cavity lips (Jeppsson, 1989, pl. 2, figs $1-3$, omitted from synonymy); it is similar to the type material (see particularly Walliser, 1964, pl. 20, fig. 16), although the cavity is not heart shaped but almost spherical in outline and most similar to morphotype A of Bultynck (1971).
Ozarkodina remscheidensis remscheidensis (Ziegler, 1960)

$$
\text { (Pl. 1, figs 21, 24; Fig. 2) }
$$

1960 Spathognathodus remscheidensis Ziegler: 194-196, pl. 13, figs $1,2,4,5,7,8,10,14(\mathrm{~Pa})$.

1969 Spathognathodus steinhornensis remscheidensis Ziegler; Fåhræus: text-fig. 1 (Pa).

1973 Ozarkodina remscheidensis remscheidensis (Ziegler); Klapper: 241-242, pl. 2, fig. $4(\mathrm{~Pa})$.

1986 Ozarkodina remscheidensis remscheidensis (Ziegler); Mawson: 49 , pl. 6, figs 1-20 (whole apparatus).

For synonymy see Uyeno $(1990, \mathrm{pp} .93,94)$ and add the following:

1964 Spathognathodus steinhornensis ssp. indet. Walliser: pl. 21, figs 3-6 (Pa).

1969 Spathognathodus inclinatus inclinatus Rhodes; Wolska: 585-586, pl. 3, figs 6, 7, $12(\mathrm{~Pa})$.

1978 Spathognathodus steinhornensis eosteinhornensis (Walliser); Helfrich: pl. 1, figs 25-27, 33, 34 (Pa).

1991 Ozarkodina remscheidensis remscheidensis (Ziegler); Uyeno: pl. 1, fig. $13(\mathrm{~Pa})$.

1992 Ozarkodina remscheidensis remscheidensis (Ziegler); Barrick \& Klapper: 49, pl. 6, figs 5-16 (Pa).

Diagnosis. A subspecies of Ozarkodina 'with a straight or slightly curved blade. Denticles are uneven in length, 1-2 directly behind the anterior margin are big and there is a single large denticle above the basal cavity. The margins of the basal cavity are flared and generally symmetrical to almost symmetrical' (translated from Ziegler, 1960, p. 64).

Holotype. Geologisches Landesamptes Nordrhein - Westfalen, Krefeld, FRG., No. G 88 b. Figured by Ziegler, 1960, pl. 13, fig. 4, from Pack 6, sample E, Remscheid Anticline, Germany (see Ziegler 1960, fig. 2).

Material. Two Pa elements.

Localities and horizons. (Figs 3, 4) Whitcliffe Formation: sample 31b/3, Tite's Point, Gloucestershire (loc. 31b). Upper Perton Beds: sample 161/1, Perton, Hereford \& Worcester (loc. 23b). A single specimen (identified by RJA) was also reported from $60 \mathrm{~cm}$ below the Temeside bone bed in the Ledbury Formation (Prídoli) of the Teme River Section, Ludlow (GR SO 522 742), by Antia (1979, p. 117).

Description. Pa element carminate with cusp slightly to anterior of cavity. Aboral margins of processes inclined upwards away from cavity to form angle of $150^{\circ}$. Denticulation uneven. Posterior process decreases in height distally, although termination broken on one specimen; proximal denticle large and similar to cusp with following three denticles decreasing rapidly in size. Posterior and anterior processes thickened parallel to oral margin at level half way between aboral margin and base of denticles. Anterior process longer than posterior, of constant height, with proximal two denticles small, followed by a tiny fused denticle. Fourth, fifth and sixth denticles larger, triangular, more isolated and of roughly equal size. Terminal denticle small, extending to three quarters height of rest of blade. Cavity lips asymmetrical, more laterally flared on one side and slightly obliquely pinched either side of blade; in lateral view, cavity lips inclined parallel to posterior aboral margin. Cavity tapering, extending under entire length of anterior process and unbroken part of posterior process. White matter fills cusp and all denticles with base subparallel to aboral margin. Accessory 
white matter patches anteriorly and posteriorly between cusp and first denticle, and between first and second denticles (Fig. 2).

\section{O. remscheidensis ssp.}

M element morphotype A

(Fig. 2, Fig. 5c)

?1975 Hindeodella steinhornensis ssp. 1. Jeppsson: 43-44, pl. 11, fig. 50.

Material. Three specimens.

Localities and horizons. (Figs 3, 4) Whitcliffe Formation: sample 8/1, Diddlebury, Corve Dale, Shropshire (loc. 8). Upper Perton Beds: sarnple 160/1, Perton, Hereford \& Worcester (loc. 23a).

Description. Bipennate; cusp stout with convex inner face, flatter outer face, sharp anterior and posterior edges. Anterior process as downward extension of cusp with three strongly fused denticles. Posterior process increases in height distally, most complete specimen (Fig. 5c) broken after sixth denticie; proximal denticles slender, small, sharp and crowded, becoming wider and more isolated distally. Cavity flared beneath cusp, tapering gradually to termination of anterior process and present as thin groove under entire preserved part of posterior process. Basal body may be retained within flared cavity, extending below cavity lips. White matter extends under entire element apart from basal cavity lips (Fig. 2).

Remarks. A specimen of this morphology was figured as a subspecies of $O$. steinhornensis by Jeppsson (1975) although alternating; denticulation typical of the remscheidensis (steinhornensis) plexus is absent. The specimen figured by Nicoll \& Rexroad (1987, pl. 3.1, fig. 4) as O. r. eosteinhornensis is very similar, but the anterior processes on the Welsh Borderland specimens are more pointed and the specimens have a fused denticle next to the cusp on the posterior process (Fig. 5c). This is a candidate $\mathrm{M}$ element for the apparatus of $O$. $r$. baccata, but the available material is too limited to test this possibility.

\section{M element morphotype B}

(Fig. 2, Figs 5d, e)

Material. 14 specimens.

Localities and horizons. (Figs 3, 4) Whitcliffe Formation: sample 39/1, Aston Munslow, Corve Dale, Shropshire (loc. 7a); sample $31 \mathrm{~b} / 4$, Tite's Point, Gloucestershire. Upper Whitcliffe Formation: sample $15 \mathrm{c} / 2$, Whitcliffe Quarry, Ludlow, Shropshire (loc. 15c); sample 77/2, Ludford Lane, Ludlow, Shropshire (loc. 17a); sample 18/1, Ludford Corner, Ludlow, Shropshire (loc. 18). Upper Perton Beds: sample 160/1, Perton Lane, Hereford and Worcester (loc. 31b); sample 162/2, Prior's Frome, Hereford and Worcester (loc. 24a).

Description. Bipennate; cusp lenticular in section with sharp anterior and posterior edges. Anterior process directed anteriorly and downwards at $45^{\circ}$, with two or three denticles strongly fused to base of cusp. Posterior process markedly curved downwards, proximal denticles upright and fused, distally becoming more isolated and posteriorly inclined. Cavity lips slightly fiared below cusp, extending as groove along entire postero-aboral margin, but only to first denticle on anterior process. Beneath each denticle there is a white matter bar which extends mid-way to the basal margin (Fig. 2).

Remarks. $M$ element morphotype $B$ occurs in association with remscheidensis $\mathrm{Pa}$ elements and those of $O$. snajdri (Walliser) in the Welsh Borderland, but is probably part of a remscheidensis apparatus. Similar elements have previously been assigned to taxa of the remscheidensis plexus (Jeppsson, 1975, pp. 39-43, pl. 10, figs 2, 3, as Hindeodella steinhornensis scanica Jeppsson; Savage, 1976, p. 1182, pl. 1, fig. 7 as $O$. remscheidensis; Helfrich, 1978 , pl. 1, fig. 22 as $O$. steinhornensis eosteinhornensis; Savage, 1982, p. 986, pl. 1, figs 19-21 as $O$. remscheidensis).

The reconstruction of $O$. r. remscheidensis by Mawson (1986) includes a broadly similar $\mathbf{M}$ element, but the Welsh specimens do not possess alternating denticulation. Lane \& Ormiston (1979) also figured a similar $\mathrm{M}$ element as $O . r$. remscheidensis but with less fused denticles. The specimen figured by Mastandrea (1985a, pl. 1, fig. 4) has a straight, not curved, posterior process, similar to that identified by Bultynck (1971, pl. 4, fig. 7) as Neoprioniodus bicurvatus (Branson \& Mehl). A specimen figured by Borremans \& Bultynck (1986, pl. 1, fig. 20) as $O$.r. remscheidensis has the same distinctive curved posterior process but the specimen is poorly preserved and the denticulation is not evident on the illustration.

\section{$\mathrm{Sb}$ element. \\ (Fig. 2, Fig. 5f)}

Material. Two specimens.

Localities and horizons. (Figs 3, 4) Whitcliffe Formation: sample 39/1, Aston Munslow, Corve Dale, Shropshire (loc. 7a); sample 8/1, Diddlebury, Corve Dale, Shropshire (loc. 8).

Description. Bipennate. Cusp lenticular in section, posteriorly inclined; posterior edge rounded, anterior edge sharp. Anterior process curved slightly inwards with alternating denticulation; repeated sequence of two broad denticles followed by narrow fused denticle, denticles increasing in size until break in specimen after fourth large denticle. Posterior process proximally straight but curved downwards distally at about $45^{\circ}$, increasing in height towards abrupt tip; proximal denticle small and fused to base of cusp, followed by two larger denticles. Alternating denticulation on straight part of process, with increasing size until largest denticle in third group of denticles is almost cusp sized; downcurved distal part of process with two large medial denticles flanked by smaller neighbours. Cavity small, lips flared to greater extent on inner margin. White matter reflects the inclination of the denticles on the anterior process and alternating denticulation of the posterior process (Fig. 2).

Remarks. The element possesses alternating denticulation which is a characteristic of some members of the remscheidensis plexus. The element possibly belongs to $O$. remscheidensis eosteinhornensis, but its posterior process is curved downwards through $45^{\circ}$ and is unlike the $\mathrm{Sb}$ element figured from the apparatus of O. r. eosteinhornensis by Mashkova (1972, pl. 2, fig. 28). It is a possible candidate $\mathrm{Sb}$ element for $O$. $r$. baccata.

\section{Manuscript received July 1994 Manuscript accepted February 1995}

\section{ACKNOWLEDGEMENTS}

CGM acknowledges receipt of NERC research studentship GT4/89/GS/056 and wishes to thank Drs J. E. Whittaker and L. R. M. Cocks for their help and use of the facilities at the Natural History Museum, London. We are also grateful to Dr Ulrike Coleman for providing German translations. 


\section{REFERENCES}

Aldridge, R. J. 1975. The stratigraphic distribution of conodonts in the British Silurian. Journal of the Geological Society, London, 131: 607 618.

Aldridge, R. J. 1985. Conodonts of the Silurian System from the British Isles. In Higgins, A. C. \& Austin, R. L. (Eds) A Stratigraphical Index of Conodonts, 68-92, 238-241. Ellis Horwood, Chichester, for British Micropalaeontological Society.

Aldridge, R. J. \& Smith, M. P. 1985. Lower Palaeozoic succession of the Welsh Borderland. Fourth European Conodont Symposium (ECOS IV) Field Excursion B Guidebook.

Aldridge, R. J. \& Schönlaub, H-P. 1989. Conodonts. In Holland, C. H. \& Bassett, M. G. (Eds) A Global Standard for the Silurian System, 274-279, National Museum of Wales Geological Series, 9.

Antia, D. D. J. 1979. Bone-beds: a review of their classification, occurrence, genesis, diagenesis, geochemistry, palaeoecology, weathering and microbiotas. Mercian Geologist, 7: 93-174.

Armstrong, H. A. 1990. Conodonts from the upper Ordovician-lower Silurian carbonate platform of North Greenland. Gronlands Geologiske Undersogelse, 159: $151 \mathrm{pp}$.

Barnett, S. G. 1971. Biometric determination of the evolution of Spathognathodus remscheidensis: A method for precise intrabasinal correlation in the northern Appalachians. Journal of Paleontology, 45: 274-301.

Barnett, S. G. 1972. The evolution of Spathognathodus remscheidensis in New York, New Jersey, Nevada, and Czechoslovakia. Journal of Paleontology, 46: 900-917.

Barnett, S. G., Kohut, J. J., Rust, C. C. \& Sweet, W. C. 1969. Conodonts from Nowshera Reef Limestones (uppermost Silurian or lowermost Devonian), West Pakistan. Journal of Paleontology, 40: 435438.

Barrick, J. E. \& Klapper, G. 1990. Henryhouse and Haragan Formations (Late Silurian-Early Devonian) and Woodford Shale (Late Devonian-Early Mississippian). In Ritter, S. M. (Ed.), Early to Middle Paleozoic Conodont Biostratigraphy of the Arbuckle Mountains, Southern Oklahoma, 11-13, Guidebook of the Oklahoma Geological Survey, 27.

Barrick, J. E. \& Klapper, G. 1992. Late Silurian-Early Devonian conodonts from the Hunton Group (Upper Henryhouse, Haragan and Bois d'Arc Formations), South-Central Oklahoma. In Chaplin, I. R. \& Barrick, J. E. (Eds) Special Papers in Paleontology and Stratigraphy: a Tribute to Thomas W. Amsden, 19-65, Bulletin of the Oklahoma Geological Survey, 145.

Barrick, J. E., Klapper, G. \& Amsden, T. W. 1990. Hunton Group (Late Ordovician-Early Devonian). In Ritter, S. M. (Ed.), Early to Middle Paleozoic Conodont Biostratigraphy of the Arbuckle Mountains, Southern Oklahoma, 5-9, Guidebook of the Oklahoma Geological Survey, 27

Borremans, G. \& Bultynck, P. 1986. Conodonts du Calcaire de Naux gedinnien inférieur au sud immediat du Massif de Rocroi (Ardenne francaise). Aardkundige Mededelingen, 3: 45-58.

Bultynck, P. 1971. Le Silurien supérieur et le Devonien inférieur de la Sierra de Guadarrama (Espagne centrale). Deuxieme partie: assemblages de conodontes à Spathognathodus. Bulletin de l'Institut royal des Sciences naturelles de Belgique, 49.

Bultynck, P. 1977. Conodontes de la Série de Liévin (Siluro-Devonien) de l'Artois (Nord de la France). Annales de la Société Géologique du Nord, 97: 11-20.

Bultynck, P. 1986. Conodontes. In Racheboeuf, P. R. (Ed.), Le Groupe de Lievin. Prídoli - Lochovien de l'artois (N. France), 201-204. Biastratigraphie du Paléozoique. University of Brittany, Brest, 3.

Bultynck, P. \& Pelhate, A. 1971. Découvert de la zone à eosteinhornensis (conodontes) dans le synclinorium médian du Massif armouricain. Memoires du Bureau des recherches Géologiques et Minières, 73: 189197.

Chlupác, I., Kríz, J. \& Schönlaub, H.-P. (with contributions from G. Klapper \& J. Zikmundova) 1980. Silurian and Devonian conodont localities of the Barrandian. In Schönlaub, H.-P. (Ed.) Guidebook and Abstracts, Second European Conodont Symposium-ECOS II, 147 180. Abhandlung der Geologischen Bundesanstalt, 35

Clark, D. L. \& Ethington, R. L. 1966. Conodonts and biostratigraphy of the Lower and Middle Devonian of Nevada and Utah. Journal of Paleontology, 40: 659-689.
Collinson, C. \& Druce, E. C. 1966. Upper Silurian conodonts from the Welsh Borderland (abstract). Bulletin of the American Association of Petroleum Geologists, 50: 608.

Cooper, B. J. 1980. Towards an improved Silurian conodont biostratigraphy. Lethaia, 13: 209-227.

Degardin, J.-M. \& Lethiers, F. 1982. Une microfaune (Conodonta, Ostracoda) dans le Silurien des Pyrenees centrales Espagnoles. Revista Española de Micropaleontología, 14: 335-358.

Drygant, D. M. 1984. Correlation and conodonts of the Silurian-lower Devonian deposits of Volyno-Podolia. Akademiya nauk Ukrainskoi SSR, Institut Geologii i Geokhimii Gorychikh Iskopaemykh, 208 pp.

Durdanovic, Z. 1967. Conodonten des älteren Pälaeozoikums (Ludlow) des Gebirges Medvenika (Zagrebacka Gora). Bulletin scientifique Conseil des académies de la PRF Yougoslavie, A12: 253-254.

Ebner, F. 1976. Das Silur/Devon-Vorkommen von Eggenfeld--ein Beitrag zur Biostratigraphic des Grazer Paläozoikums. Mitteilungen der Abteilung Paläontologie und Bergbau am Landesmuseum Joanneum, Graz, 37: 276-305.

Fåhræus, L. 1969. Spathognathodus remscheidensis Ziegler, 1960 and the age of the Ohessaare Stage of Estonia: a reply to Kaljo, D. \& Viira, V Geologiska Föreningens i Stockholm Forhändlingar, 91: 433-435.

Fåhræus, L. 1974. Taxonomy and evolution of Ozarkodina steinhornensis and Ozarkodina optima (Conodontophorida). Geologica et Palaeontologica, 8: 29-37.

Feist, R. \& Schönlaub, H-P. 1974. Zur Silur/Devon Grenze in der östlichen Montagne Noire Süd - Frankreichs. Neues Jahrbuch für Geologie und Paläeontologie Monatshefte, 4: 200-219.

Gnoli, M., Kriz, J., Leone, F., Olivieri, R., Serpagli, E. \& Storch, P. 1990. Lithostratigraphic units and biostratigraphy of the Silurian and early Devonian of southwest Sardinia. Bolletino della Società Paleontologica Italiana, 29: 11-23.

Harris, A., Hatch, N. L. \& Dutro, J. T., Jr 1983. Late Silurian conodonts update the metamorphosed Fitch Formation, Littleton area, New Hampshire. American Journal of Science, 283: 722-738.

Helfrich, C. T. 1975. Silurian conodonts from the Wills Mountain Anticline, Virginia, West Virginia and Maryland. Special Paper of the Geological Society of America, 161.

Helfrich, C. T. 1978. A conodont fauna from the Keyser Limestone of Virginia and West Virginia. Journal of Paleontology, 52: 1133-1142.

Higgins, A. C. 1975. Conodont zonation of the late Visean-Early Westphalian strata of the South and Central Pennines of Northern England. Bulletin of the Geological Survey of Great Britain, 53: 1-90

Jaeger, H. \& Schönlaub, H.-P. 1980. Silur und Devon nördlich der Gundersheimer Alm in den Karnischen Alpen (Österreich). Carinthia II, 170/90: 403-444.

Jeppsson, L. 1975 [dated 1974]. Aspects of Late Silurian conodonts. Fossils \& Strata, 6: 1-54.

Jeppsson, L. 1988 Conodont biostratigraphy of the Siluro-Devonian boundary stratotype at Klonk, Czechoslovakia. Geologica et Palaeontologica, 22: 21-31.

Jeppsson, L. 1989. Latest Silurian conodonts from Klonk, Czechoslovakia. Geologica et Palaeontologica, 23: 21-37.

Klapper, G. 1969. Lower Devonian conodont sequence, Royal Creek, Yukon Territory and Devon Island, Canada, with a section on Devon Island stratigraphy by A.R. Ormiston. Journal of Paleontology, 43: 127.

Klapper, G. 1973. Ozarkodina remscheidensis remscheidensis (Ziegler, 1960 ) and Ozarkodina remscheidensis eosteinhornensis (Walliser, 1964) In Ziegler, W. (Ed.) A Catalogue of Conodonts, Volume 1, 241-244. Schweizerbart'sche Verlagsbuchhandlung, Stuttgart, 504 pp.

Klapper, G. \& Murphy, M. A. 1974. Silurian-Lower Devonian conodont sequence in the Roberts Mountains Formation of Central Nevada. University of California Publications in Geological Sciences, 111.

Kleffner, M. A. 1989. A conodont based chronostratigraphy. Bulletin of the Geological Society of America, 101: 904-912.

Lane, H. R. \& Ormiston, A. R. 1979. Siluro-Devonian biostratigraphy of the Salmontrout River area, east-central Alaska. Geologica et Palaeontologica, 13: 39--95.

Legault, J. A. 1968. Conodonts and fish remains from the Stonehouse Formation, Arisaig, Nova Scotia. Bulletin of the Geological Survey of Canada, 165: 1-45. 
Link, A. G. \& Druce, E. C. 1972. Ludlovian and Gedinnian conodont stratigraphy of the Yass Basin, New South Wales. Bulletin of the Bureau of Mineral Resources, Geology and Geophysics, Australia, 134.

Mashkovi, T. V. 1972. Ozarkodina steinhornensis (Ziegler) apparatus, its conodonts and biozone. In Lindström, M. \& Ziegler, W. (Eds) Symposium on Conodont Taxonomy, 81-90, Sonderband Geologica et Palaeontologica, 1.

Mastandrea, A. 1985a. Early Devonian (Lochkovian) conodonts from southwestern Sardinia. Bolletino della Società Paleontologica Italiana, 23: $240-258$.

Mastandrea, A. 1985b. Biostratigraphic remarks on Early Devonian conodonts from Corti Baccas III section (SW Sardinia). Bolletino della Società Paleontologica Italiana, 23: 259-267.

Mawson, F. 1986. Early Devonian (Lochkovian) conodont faunas from Windellama, New South Wales. Geologica et Palaeontologica, 20: 39 71 .

Mehrtens, C. J. \& Barnett, S. G. 1977. Conodont subspecies from the Upper Silurian-Lower Devonian of Czechoslovakia. Micropaleontology, 22: 491-500.

Miller, C. G. \& Aldridge, R. J. 1993. Taxonomy and apparatus structure of the Silurian distomodontid conodont Coryssognathus Link and Druce, 1972. Journal of Micropalaeontology, 12: 241-255.

Nicoll, R. S. \& Rexroad, C. B. 1987. Re-examination of conodont clusters from northern Indiana. In Aldridge, R. J. (Ed.) Palaeobiology of Conodonts, 49-61, Ellis Horwood, Chichester, for the British Micropalkeontological Society.

Olivieri, R. \& Serpagli, E. 1990. Latest Silurian-early Devonian conodonts from the Mason Porcus Section near Fluminimaggiore, southwestim Sardinia. Bolletino della Società Paleontologica Italiana, 29: $56-76$.

Philip, G. M. 1966. Lower Devonian conodonts from the Buchan Group, eastern Victoria. Micropaleontology, 12: 441-460.

Pollock, C. A. \& Rexroad, C. B. 1973. Conodonts from the Salina Formation and the upper part of the Wabash Formation (Silurian) in north-central Indiana. Geologica et Palaeontologica, 7: 77-92.

Rexroad, C. B. \& Craig, W. W. 1971. Restudy of the conodonts from the Bainbridge Formation (Silurian) at Lithium, Missouri. Journal of Paleontology, 45: 684-703.

Saladzius, V. J. 1971. Stratigraphic value of the conodonts from the Jura Horizon of the south Baltic [in Russian with English summary]. In Grigialis, A. A. (Ed.) Palaeontologiia $i$ stratigrafia Pribaltiki $i$ Belorussil, 3: 71-76.

Savage, N. M. 1973. Lower Devonian conodonts from New South Wales. Palaeontology, 16: 307-333.

Savage, N. M. 1976. Lower Devonian conodonts from the Grouse Creek area, Klarnath Mountains, northern California. Journal of Paleontolog;, 50: 1180-1190.

Savage, N. M. 1982. Lower Devonian (Lochkovian) conodonts from Lulu Island. southeastern Alaska. Journal of Paleontology, 56: $983-$ 988.

Schönlaub, H.-P. (Ed.) 1980, Guidebook and abstracts, Second European Conodont Symposium- ECOS II. Abhandlung der Geologischen Bundesanstalt, 35.

Schönlaub, H.-P. 1986 [dated 1985]. Devonian conodonts from section Oberbuchach II in the Carnic Alps, Austria. In Ziegler, W. \& Werner (Eds) Devonian Series Boundaries - Results of Worldwide Studies, 353374, Courier Forschungsinstitut Senckenberg, 75.

Schulze, R. 1968. Die Conodonten aus dem Paläozoikum der mittleren Karawanken (Seeberggebiet). Neues Jahrbuch für Geologie und Paläontologie Abhandlung, 130: 133-245.

Serpagli, E. \& Mastandrea, A. 1970. Conodont assemblages from the Silurian-Devonian boundary beds of southwestern Sardinia (Italy). Bolletino della Società Palaeontologica Italiana, 9: 76-96.

Spassov, H. 1971. Die Conodontenchromologie des Unterdevons im
Mittelteil der Balkenhalbinsel. Izvestiia na geologicheskiia institut, komitet po geologiia, Bulgarska akademiia na naukite, seriia stratigrafia i litologiia, 20: 5-14.

Telford, P. G. 1975. Lower and Middle Devonian Conodonts from the Broken River Embayment, North Queensland, Australia. Special Papers in Palaeontology, 15.

Uyeno, T. T. 1981 [dated 1980]. Stratigraphy and conodonts of Upper Silurian and Lower Devonian rocks in the environs of the Boothia Uplift, Canadian Arctic Archipelago. Part II, Systematic study of conodonts. Bulletin of the Geological Survey of Canada, 292: 39-75.

Uyeno, T. T. 1990. Biostratigraphy and conodont faunas of Upper Ordovician through Middle Devonian rocks, eastern Arctic Archipelago. Bulletin of the Geological Survey of Canada, 401.

Uyeno, T. T. 1991. Pre-Famennian Devonian conodont biostratigraphy of selected intervals in the eastern Canadian Cordillera. In Orchard, M. J. \& McCracken, A. D. (Eds), Ordovician to Triassic Conodont Paleontology of the Canadian Cordillera, 129-161. Bulletin of the Geological Survey of Canada, 417.

Viira, V. 1983. Upper Silurian Spathognathodus (conodonts) from Estonia. In Kaljo D. (Ed.) Lower Palaeozoic Palaeontology of the Baltics and Podolia, 41-71. Estonian SSR Academy of Sciences, Institute of Geology, Tallinn.

Walliser, O. H. 1957. Conodonten aus dem oberen Gotlandium Deutschlands und der Karnischen Alpen. Landesamptes Bodenforschung Notizblatz, 85: 28-52.

Walliser, O. H. 1962. Conodontenchronologie des Silurs (=Gotlandiums) und des tieferen Devons mit besonderer Berücksichtigung der Formationsgrenze. In Erben, H. K. (Ed.), Symposiums Band der zweiten International Arbeitstagung über die Stratigraphie von Silur und Devon, Bonn-Bruxelles 1960, 281-287. E. Schweitzerbart, Stuttgart.

Walliser, O. H. 1964. Conodonten des Silurs. Abhandlungen des hessischen Landsamptes für Bodenforschung, $\mathbf{4 1 .}$.

Walliser, O. H. 1966. Die Silur/ Devon Grenze. Neues Jahrbuch für Geologie und Paläontologie Abhandlungen, 125: 235-246.

Walliser, O. H. 1971. Conodont biostratigraphy of the Silurian of Europe. In Sweet, W. C. \& Bergström, S. M., (Eds) Symposium on Conodont Biostratigraphy, 195-206. Memoir of the Geological Society of America, 127.

Walmsley, V. G., Aldridge, R. J. \& Austin, R. L. 1974. Brachiopod and conodont faunas from the Silurian and Lower Devonian of Bohemia. Geologica et Palaeontologica, 8: 39-47.

Wang, C.-y. 1981. Lower Devonian conodonts from the Xiaputonggou Formation at Zoige, NW Sichuan. Bulletin of the X'ian Institute of Geology and Mineral Resources, Chinese Academy of Geological Sciences, 3: 76-84.

Wang, C.-y. 1985. Silurian and Lower Devonian conodonts from Darhan Mumingan Joint Banner, Inner Mongolia [in Chinese with English summary]. In Li, W.-g, Rong, J.-y. \& Dong, D.-y. (Eds) Silurian and Devonian Rocks and Faunas of the Bateaobao Area in Darhan Mumingan Joint Banner, Inner Mongolia, 153-164. People's Publishing House of Inner Mongolia.

Wang, C.-y. \& Li, D.-y. 1986. Conodonts from the Ertaogou Formation in central Jilin Province [in Chinese with English summary]. Acta Micropalaeontologica Sinica, 3: 421-428.

Wang, C.-y. \& Ziegler, W. 1983. Conodonten aus Tibet. Neues Jahrbuch für Geologie und Paläontologie, Monatshefte, 2: 69-79.

Wolska, Z. 1969. Konodonty z wiercenia Chelm. Acta Palaeontologica Polonica, 14: 577-590.

Ziegler, W. 1956. Unterdevonische conodonten insbesondere aus dem Schönauer - und dem Zorgensis-Kalk. Notizblatz des hessischen Landsamptes für Bodenforschung, 84: 93-106.

Ziegler, W. 1960. Conodonten aus dem Rheinischen Unterdevon (Gedinnium) des Remscheider Sattels (Rheinisches Schiefergebirge). Paläontologishe Zeitschrift, 34: 169-201. 